Note

\title{
Comprehensive T-matrix reference database: A 2009-2011 update
}

\author{
Nadezhda T. Zakharova ${ }^{\mathrm{a}, *}$, Gorden Videen ${ }^{\mathrm{b}}$, Nikolai G. Khlebtsov ${ }^{\mathrm{c}}$ \\ ${ }^{a}$ Trinnovim/NASA Goddard Institute for Space Studies, 2880 Broadway, New York, NY 10025, USA \\ ${ }^{\mathrm{b}}$ US Army Research Laboratory, AMSRL-IS-EE, 2800 Powder Mill Road, Adelphi, MD 20783-1197, USA \\ ${ }^{\mathrm{c}}$ Institute of Biochemistry and Physiology of Plants and Microorganisms, Russian Academy of Sciences, 13 Entuziastov Ave., 410015 Saratov, Russia
}

\section{A R T I C L E I N F O}

Article history:

Received 10 April 2012

Accepted 10 April 2012

Available online 5 May 2012

Keywords:

Electromagnetic scattering

$T$-matrix method

Nonspherical particles

Many-particle aggregates

\begin{abstract}
A B S T R A C T
The $T$-matrix method is one of the most versatile and efficient theoretical techniques widely used for the computation of electromagnetic scattering by single and composite particles, discrete random media, and particles in the vicinity of an interface separating two half-spaces with different refractive indices. This paper presents an update to the comprehensive database of peer-reviewed $T$-matrix publications compiled by us previously and includes the publications that appeared since 2009. It also lists several earlier publications not included in the original database.
\end{abstract}

(c) 2012 Elsevier Ltd. All rights reserved.

\section{Introduction}

The initial database of $T$-matrix publications appeared in 2004 [1] and was followed by three updates [2-4]. As evidenced by numerous citations, this database has proved to be very useful, thereby justifying the current update. The total number of newly added references is 289 [5-293]. They mostly represent publications that appeared since 2009 plus a few publications omitted inadvertently in Refs. [1-4].

As in Refs. [1-4], the database has been compiled using the following general restrictions:

- The database contains only publications dealing with electromagnetic scattering.

- In general, publications on scattering by isolated infinite cylinders and systems of parallel infinite cylinders in unbounded space are excluded.

- Publications on the Lorenz-Mie theory and its various extensions to radially inhomogeneous spherically symmetric scatterers are not included.

\footnotetext{
* Corresponding author. Fax: +1 2126785552.

E-mail address: nadezhda.zakharova@nasa.gov (N.T. Zakharova).
}

- The database contains only references to books, peerreviewed book chapters, and peer-reviewed journal papers.

Furthermore, we have continued to use the following operational definition of the $T$-matrix method:

In the $T$-matrix method, the incident and scattered electric fields are expanded in series of suitable vector spherical wave functions, and the relation between the columns of the respective expansion coefficients is established by means of a transition matrix (or $T$ matrix). This concept can be applied to the entire scatterer as well as to separate parts of a composite scatterer.

Obviously, this definition is more inclusive than the original notion of the extended boundary condition method [294].

As before, the various references are classified into a set of narrower subject categories. Following the methodology adopted in Refs. [1-4], we do not assess the validity and importance of the results described in the specific publications included in this database. As a consequence, the inclusion of a publication does not constitute any formal endorsement or quality certification. Also, we do not flag specifically those publications in which well known results (such as the superposition 
$T$-matrix method or certain symmetry and transformation properties of the $T$ matrix) are re-discovered.

Among the many recent advances, we particularly note the following:

- The publication of two specialzed monographs $[211,218]$.

- The public release of a new version of the popular superposition $T$-matrix FORTRAN program intended for use on distributed memory computer clusters [151].

- Extensive use of the superposition $T$-matrix method for numerically exact computations of electromagnetic scattering by discrete random media, periodic multiparticle arrays, and morphologically complex multiparticle clusters.

- Theory and calculations of optical resonances in nonspherical particles and particle clusters.

- Calcutaions of optical forces and torques on small particles with application to optical traps.

- Extensive calculations of internal, surface, and local fields as well as near-field transfer of electromagnetic energy.

- Extensive use of the $T$-matrix method in analyses of laboratory data, including the results of controlled laboratory experiments.

- Extensive applications to the modeling of scattering properties of mineral and soot aerosols; cirrus cloud particles and hydrometeors; stratospheric and mesospheric aerosol and cloud particles; interstellar, interplanetary, and cometary dust particles, planetary regoliths, and planetary ring particles; biological microorganisms.

The full range of applications of the $T$-matrix method is, of course, significantly broader.

\section{Particles in infinite homogeneous space}

\subsection{Books}

$[171,211,218]$

\subsection{Reviews}

$[52,79,119,144,172,179,253]$

2.3. Extended boundary condition method and its modifications and generalizations

$[53,61-63,68,70,92,101,202-206,218,219,236,237$, $264,282,284]$

2.4. T-matrix theory and computations for anisotropic, chiral, magnetic, and charged scatterers

$[118,133,134,233]$
2.5. Superposition T-matrix method and its modifications, including related mathematical tools

$[23,54,118,123,133,134,136,137,151,152,177,193$, $194,225]$

2.6. T-matrix theory of electromagnetic scattering by periodic and aperiodic configurations of particles and photonic crystals

$$
[39,83,86,126,137,192,242,257,258,275]
$$

2.7. T-matrix theory and computations of electromagnetic scattering by discrete random media

$[52,55,117,147,150,151,169,170,171$, $173,199,207,253,256,266]$

2.8. Relation of the T-matrix method to other theoretical approaches

$[17,61-63,85,145,218,219,265]$

2.9. Symmetry properties of the T-matrix, analytical ensemble-averaging approaches, and linearization

$$
[59,71,101,106,204,241]
$$

2.10. Convergence of various implementations of the T-matrix method

$$
[61,70,81,92,108,219,225,237]
$$

2.11. T-matrix calculations for homogeneous spheroids

$[5,7,9,13,15,16,21,22,24,27,29,34,35,37,38,47,53,56$, 62-68,70-74,76-79,88-91,93,96,102,103,110,112,115, $124,125,128-131,135,146,155,157,159-165,167,173$, 175,181-184,187,197,201,204, 208,210,212,216,217, 218,224,227-229,233,238,239,241,246,248,251,254, $259,261,262,268,270,272,276,279-281,284,287]$

2.12. T-matrix calculations for Chebyshev and generalized Chebyshev particles

$[8,60,62,63,101,102,209,218,241,280]$

2.13. T-matrix calculations for finite circular cylinders

$[6,11,12,18,60,64,71,82,113,153,162,173,218$, $230,242,257,258,274,277,280]$

2.14. T-matrix calculations for various rotationally symmetric particles

$[68,71,92,108,109,156,203,206,292,293]$

2.15. T-matrix calculations for ellipsoids, polyhedral scatterers, and other particles lacking axial symmetry

$[10,94,101,186,202,205,206]$ 
2.16. T-matrix calculations for layered and composite particles

$[5,35,142,152,249,250,271,282]$

2.17. T-matrix calculations for clusters of homogeneous spheres

$[8,19,21,25,26,30,32,33,40-43,45-$

$52,55,69,75,83,86,97-100,111,114-117,120,122,126,132$, $138-140,147,148,150,151,154,166,168,169,170,173-175$, $178,185,191,195,196,199,207,214,215,221-223,225,226$, $231,234,235,240,243-245,253,255,260,266,273,275,278$, $283,285,288,289]$

2.18. T-matrix calculations for clusters of layered, anisotropic, and chiral spheres

$$
[23,118,136,137,152]
$$

2.19. T-matrix calculations for clusters of nonspherical monomers

2.20. T-matrix calculations for particles with one or several (eccentric) inclusions

$[107,141,249,269,271]$

2.21. T-matrix calculations of optical resonances in nonspherical particles

$[30,32,83,109,141,154,195,196,215,216,223,226,238$, $239,255,271,273,275]$

2.22. T-matrix calculations of optical forces and torques on small particles

$[11,12,104,143,156,178,179,188,190,198,213,223$, $232,233,245,286]$

2.23. T-matrix calculations of internal, surface, and local fields and near-field energy exchange

[19,28,33,48,49,53,61,68,137,151,152,177,221,225,269]

2.24. Illumination by focused beams and non-plane waves

$[11,23,85,104,107,133,143,150,178,198$, $213,232,269,271,286]$

2.25. Use of T-matrix calculations for testing other theoretical techniques

$[6,16,35,41-43,60,62,68,94,95,114,122,139,140,148$, $166,189,196,204,233,240,273,281,290]$
2.26. Comparisons of T-matrix and effective-mediumapproximation results

$[55,122,142,180]$

2.27. Comparisons of T-matrix and controlled laboratory results

$[111,120,166,216,260]$

2.28. Use of T-matrix calculations for analyzing laboratory data

$[8,25,26,29,69,77-79,88,102,104,110,154,159,161$, $178,187,188,217,220,230,240,244,272,273,292,293]$

2.29. T-matrix modeling of scattering properties of mineral aerosols in the terrestrial atmosphere and soil particles

$[10,15,20,24,31,37,58,67,72-74,76,89,90,96,103,110$, $112,125,155,161-163,165,168,174,181,182$, $184,186,212,214,227,228,230,247,248,251,254,261$, $262,268,276,287]$

2.30. T-matrix modeling of scattering properties of carbonaceous and soot aerosols and soot-containing aerosol and cloud particles

$[5,40,42,43,97-100,132,138-140,142,148$, $168,249,280,288,289]$

2.31. T-matrix modeling of scattering properties of cirrus cloud particles

$[22,57,82,158,229,274]$

2.32. T-matrix modeling of scattering properties of hydrometeors and atmospheric radar targets

$[13,21,27,34-36,57,80,84,105,121,127-129,130$, $131,135,164,200,224,252,259,267,279,291]$

2.33. T-matrix modeling of scattering properties of terrestrial stratospheric aerosol and cloud particles

$[124,208]$

2.34. T-matrix modeling of scattering properties of noctilucent cloud particles

$[14,91,93,160,201]$

2.35. T-matrix modeling of scattering properties of hydrosol particles

$[7,113,146,157]$

2.36. T-matrix modeling of scattering properties of aerosol and cloud particles in planetary atmospheres

$[44,153,234,235,263,277]$ 
2.37. T-matrix modeling of scattering properties of interstellar, interplanetary, cometary, and planetary-ring particles

$[38,45-47,51,114-116,118,147,191]$

\author{
2.38. T-matrix computations for industrial and military \\ applications
}

$[167,209]$

2.39. T-matrix computations for biomedical applications

[7,29,56,64-66,79,126,187,190,209,213,244,246,272]

2.40. T-matrix computations of anisotropic and aggregation properties of colloids and other disperse media

$[55,69,108,111,278,283,293]$

\section{Particles near infinite interfaces}

\subsection{Spherically symmetric particles}

$[149,176]$

\subsection{Finite particles on incident side of planar interface}

$[149,176]$

\section{Acknowledgments}

We thank Josefina Mora and Zoe Wai for helping to obtain copies of publications that were not readily accessible. This project was sponsored by NASA.

\section{References}

[1] Mishchenko MI, Videen G, Babenko VA, et al. T-matrix theory of electromagnetic scattering by particles and its applications: a comprehensive reference database. J Quant Spectrosc Radiat Transfer 2004;88:357-406.

[2] Mishchenko MI, Videen G, Babenko VA, et al. Comprehensive T-matrix reference database: a 2004-2006 update. J Quant Spectrosc Radiat Transfer 2007;106:304-24.

[3] Mishchenko MI, Videen G, Khlebtsov NG, et al. Comprehensive T-matrix reference database: a 2006-2007 update. J Quant Spectrosc Radiat Transfer 2008;109:1447-60.

[4] Mishchenko MI, Zakharova NT, Videen G, et al. Comprehensive T-matrix reference database: a 2007-2009 update. J Quant Spectrosc Radiat Transfer 2010;111:650-8.

[5] Adler G, Riziq AA, Erlick C, Rudich Y. Effect of intrinsic organic carbon on the optical properties of fresh diesel soot. Proc Natl Acad Sci USA 2010;107:6699-704.

[6] Alyones S, Bruce CW. Electromagnetic scattering by finite conducting fiber: limitation of a previous published code. J Electromagn Waves Appl 2011;25:1021-30.

[7] Andrews S, Nover D, Schladow SG. Using laser diffraction data to obtain accurate particle size distributions: the role of particle composition. Limnol Oceanogr: Meth 2010;8:507-26.

[8] Auger JC, Fernandes GE, Aptowicz KB, et al. Influence of surface roughness on the elastic-light scattering patterns of micron-sized aerosol particles. Appl Phys B 2010;99:229-34.

[9] Bai L, Wu ZS, Li HY, Li T. Scalar radiative transfer in discrete media with random oriented prolate spheroids particles. Prog Electromagn Res B 2011;33:21-44.
[10] Baran AJ. A new application of a multifrequency submillimeter radiometer in determining the microphysical and macrophysical properties of volcanic plumes: a sensitivity study. J Geophys Res 2012;117:D00U18.

[11] Bareil PB, Sheng Y. Study of angular and position stability in optical trap of a nanorod. Proc SPIE 2010:7762:77621A.

[12] Bareil PB, Sheng Y. Angular and position stability of a nanorod trapped in an optical tweezers. Opt Express 2010;18:26388-98.

[13] Battaglia A, Saavedra P, Rose T, Simmer C. Characterization of precipitating clouds by ground-based measurements with the triple-frequency polarized microwave radiometer ADMIRARI. J Appl Meteorol Climatol 2010;49:394-414.

[14] Baumgarten G, Chandran A, Fiedler J, et al. On the horizontal and temporal structure of noctilucent clouds as observed by satellite and lidar at ALOMAR (69 N). Geophys Res Lett 2012;39:L01803.

[15] Bennouna YS, de Leeuw G, Piazzola J, Kusmierczyk-Michulec J. Aerosol remote sensing over the ocean using MSG-SEVIRI visible images. J Geophys Res 2009;114:D23203.

[16] Berg MJ, Wilson KR, Sorensen CM, et al. Discrete dipole approximation for low-energy photoelectron emission from NaCL nanoparticles. J Quant Spectrosc Radiat Transfer 2012;113:259-65.

[17] Bi L, Yang P, Kattawar GW. On the far field in the Lorenz-Mie theory and T-matrix formulation. J Quant Spectrosc Radiat Transfer 2010;111:515-8.

[18] Bi L, Yang P, Kattawar GW. Edge-effect contribution to the extinction of light by dielectric disks and cylindrical particles. Appl Opt 2010;49:4641-6.

[19] Blaber MG, Schatz GC. Extending SERS into the infrared with gold nanosphere dimers. Chem Commun 2011;47:3769-71.

[20] Boesch H, Baker D, Connor B, et al. Global characterization of $\mathrm{CO}_{2}$ column retrievals from shortwave-infrared satellite observations of the Orbiting Carbon Observatory-2 mission. Remote Sens 2011;3:270-304.

[21] Botta G, Aydin K, Verlinde J. Modeling of microwave scattering from cloud ice crystal aggregates and melting aggregates: a new approach. IEEE Geosci Remote Sensing Lett 2010;7:572-6.

[22] Botta G, Aydin K, Verlinde J, et al. Millimeter wave scattering from ice crystals and their aggregates: comparing cloud model simulations with X- and Ka-band radar measurements. J Geophys Res 2011;116:D00T04.

[23] Boyde L, Chalut KJ, Guck J. Near- and far-field scattering from arbitrary three-dimensional aggregates of coated spheres using parallel computing. Phys Rev E 2011;83:026701.

[24] Budak V, Korkin SV, Korolev KN. Defining the shape of particles based on the polarisation state of the scattered optical radiation. Proc SPIE 2009;7475:747519.

[25] Bunkin NF, Shkirin AV, Kozlov VA, Laser scattering in water and aqueous solutions of salts. Proc SPIE 2010;7376:73761D.

[26] Bunkin NF, Ninham BW, Ignatiev PS, et al. Long-living nanobubbles of dissolved gas in aqueous solutions of salts and erythrocyte suspensions. J Biophoton 2011;4:150-64.

[27] Cao Q, Yeary MB, Zhang G. Efficient ways to learn weather radar polarimetry. IEEE Trans Education 2012;55:58-68.

[28] Carrillo LY, Bayazitoglu Y. Sphere approximation for nanorod near-field radiative heat exchange analysis. Nanoscale Microscale Thermophys Eng 2011;15:195-208.

[29] Chalut KJ, Kulangara K, Giacomelli MG, et al. Deformation of stem cell nuclei by nanotopographical cues. Soft Matter 2010;6: 1675-81.

[30] Chang W-S, Willingham BA, Slaughter LS, et al. Low absorption losses of strongly coupled surface plasmons in nanoparticle assemblies. Proc Natl Acad Sci USA 2011;108:19879-84.

[31] Chazette P, Bocquet M, Royer P, et al. Eyjafjallajökull ash concentrations derived from both lidar and modeling. J Geophys Res 2012;117:D00U14.

[32] Chen SY, Lazarides AA. Quantitative amplification of surface enhanced Raman scattering through plasmonic coupling in controlled nanoparticle assemblies. Proc SPIE 2009;7395:73951S.

[33] Chen SY, Lazarides AA. Manipulation of near field polarization by far field excitation. Proc SPIE 2010;7604:76041B.

[34] Chen K-S, Chu C-Y, Tzeng Y-C. A semi-empirical model of rain attenuation at Ka-band in northern Taiwan. Prog Electromagn Res M 2011;16:213-23.

[35] Chen J, Chen R, Liu Z, et al. Analysis of EM scattering of precipitation particles in dual-band. Appl Comput Electromagn Soc J 2011;26: 709-15.

[36] Chen J-Q Chen R-S, Peng H, et al. Analysis of electromagnetic properties of precipitation particle and imaging simulation of target in rainfall environment. Chinese J Radio Sci 2011;26:888-93. 
[37] Cheng TH, Gu XF, Yu T, Tian GL. The reflection and polarization properties of non-spherical aerosol particles. J Quant Spectrosc Radiat Transfer 2010;111:895-906.

[38] Cho J, Lazarian A. Galactic foregrounds: spatial fluctuations and a procedure for removal. Astrophys J 2010;720:1181-201.

[39] Christofi A, Stefanou N, Gantzounis G, Papanikolaou N. Spiralstaircase photonic structures of metallic nanorods. Phys Rev B 2011;84:125109.

[40] Chung CE, Lee K, Müller D. Effect of internal mixture on black carbon radiative forcing. Tellus B 2012;64:10925.

[41] Cui Z, Han Y, Xu Q. Numerical simulation of multiple scattering by random discrete particles illuminated by Gaussian beams. J Opt Soc Am A 2011;28:2200-8.

[42] Cui ZW, Han YP, Li CY. Characterization of the light scattering by ensembles of randomly distributed soot aggregates. J Quant Spectrosc Radiat Transfer 2011;112:2722-32.

[43] Cui Z, Han Y, Zhao W. Scattering of arbitrarily incident Gaussian beams by fractal soot aggregates. J Opt A: Pure Appl Opt 2012;14: 035703.

[44] Daerden F, Whiteway JA, Davy R, et al. Simulating observed boundary layer clouds on Mars. Geophys Res Lett 2010;37:L04203.

[45] Das HS, Sen AK. Model for cometary grains to explain optical polarization. J Quant Spectrosc Radiat Transfer 2011;112:1833-7.

[46] Das HS, Suklabaidya A, Majumder SD, Sen AK. Aggregate dust model to study the polarization properties of comet C/1996 B2 Hyakutake. Res Astron Astrophys 2010;10:355-62.

[47] Das HS, Paul D, Suklabaidya A, Sen AK. Modelling the polarization properties of Comet $1 \mathrm{P} /$ Halley using a mixture of compact and aggregate particles. Mon Not Roy Astron Soc 2011;416:94-100.

[48] Deng C-S, Xu H, Deych L. Optical transport and statistics of radiative losses in disordered chains of microspheres. Phys Rev A 2010;82:041803.

[49] Deng C-S, Xu H, Deych L. Effect of size disorder on the optical transport in chains of coupled microspherical resonators. Opt Express 2011;19:6923-37.

[50] Deych L, Rubin J. Rayleigh scattering of whispering gallery modes of microspheres due to a single dipole scatterer. Phys Rev A 2009;80:061805.

[51] Dlugach JM, Mishchenko MI, Mackowski DW. Numerical simulations of single and multiple scattering by fractal ice clusters. J Quant Spectrosc Radiat Transfer 2011;112:1864-70.

[52] Dlugach JM, Mishchenko MI, Liu L, Mackowski DW. Numerically exact computer simulations of light scattering by densely packed, random particulate media. J Quant Spectrosc Radiat Transfer 2011;112:2068-78.

[53] Doicu A, Wriedt T. Near-field computation using the null-field method. J Quant Spectrosc Radiat Transfer 2010;111:466-73.

[54] Dong NT, Tanaka M, Tanaka K. Improved algorithms for calculating addition coefficiens in electromagnetic scattering by multisphere systems. IEICE Tran Electron 2012;E95-C:27-35.

[55] Doyle TE, Tew AT, Jain R, Robinson DA. Effects of aggregation on the permittivity of random media containing monodisperse spheres. J Appl Phys 2009;106:114104.

[56] Dyatlov GV, Gilev KV, Yurkin MA, Maltsev VP. An optimization method with precomputed starting points for solving the inverse Mie problem. Inverse Probl 2012;28:045012.

[57] Eriksson P, Buehler SA, Davis CP, et al. ARTS, the atmospheric radiative transfer simulator, version 2. J Quant Spectrosc Radiat Transfer 2011;112:1551-8.

[58] Esparza AE, Fitzgerald RM, Gill TE, Polanco J. Use of light-extinction method and inverse modeling to study aerosols in the Paso del Norte Airshed. Atmos Environ 2011;45:7360-9.

[59] Farafonov VG. A unified approach, using spheroidal functions, for solving the problem of light scattering by axisymmetric particles. J Math Sci 2011;175:698-723.

[60] Farafonov VG, Il'in VB. On scattering of light by small axially symmetric particles. Opt Spectrosc 2011;111:824-31.

[61] Farafonov VG, Il'in VB, Vinokurov AA. Near- and far-field light scattering by nonspherical particles: applicability of methods that involve a spherical basis. Opt Spectrosc 2010;109:432-43.

[62] Farafonov VG, Vinokurov AA, Barkanov SV. Electrostatic solution and Rayleigh approximation for small nonspherical particles in a spheroidal basis. Opt Spectrosc 2011;111:980-92.

[63] Farafonov VG, Barkanov SV, Il'in VB, Vinokurov AA. Light scattering by small axisymmetric particles using a generalized method of separation of variables with a spherical basis. J Opt Technol 2011;78:544-50.

[64] Feng C, Huang L, Han J, et al. Light scattering modeling of bacteria using spheroids and cylinders. Proc SPIE 2009;7511: 75110P.
[65] Feng C, Huang L, Zhou G, et al. Computation and analysis of light scattering by monodisperse biological aerosols. Chinese J Lasers 2010;37:2592-8.

[66] Feng C, Huang L, Wang J, et al. Theoretical studies on bioaerosol particle size and shape measurement from spatial scattering profiles. Chinese Opt Lett 2011;9:092901.

[67] Feng O, Hsu NC, Yang P, Tsay SC. Effect of thin cirrus clouds on dust optical depth retrievals from MODIS observations. IEEE Trans Geosci Remote Sens 2011;49:2819-27.

[68] Forestiere C, Iadarola G, Dal Negro L, Miano G. Near-field calculation based on the T-matrix method with discrete sources. J Quant Spectrosc Radiat Transfer 2011;112:2384-94.

[69] Fung J, Martin KE, Perry RW, et al. Measuring translational, rotational, and vibrational dynamics in colloids with digital holographic microscopy. Opt Express 2011;19:8051-65.

[70] Ganesh M, Hawkins SC. Three dimensional electromagnetic scattering T-matrix computations. J Comput Applied Math 2010;234:1702-9.

[71] Gantzounis G. Plasmon modes of axisymmetric metallic nanoparticles: a group theory analysis. J Phys Chem C 2009;113:21560-5.

[72] Gasteiger J, Gro $\beta$ S, Freudenthaler V, Wiegner M. Volcanic ash from Iceland over Munich: mass concentration retrieved from ground-based remote sensing measurements. Atmos Chem Phys Discuss 2010;10:26705-34.

[73] Gasteiger J, Gro $\beta$ S, Freudenthaler V, Wiegner M. Volcanic ash from Iceland over Munich: mass concentration retrieved from ground-based remote sensing measurements. Atmos Chem Phys 2011;11:2209-23.

[74] Gasteiger J, Wiegner M, Gro $\beta$ S, et al. Modelling lidar-relevant optical properties of complex mineral dust aerosols. Tellus B 2011;63:725-41.

[75] Gay B, Vaillon R, Mengüç MP. Polarization imaging of multiplyscattered radiation based on integral-vector Monte Carlo method. J Quant Spectrosc Radiat Transfer 2010;111:287-94.

[76] Ge JM, Su J, Fu Q, et al. Dust aerosol forward scattering effects on ground-based aerosol optical depth retrievals. J Quant Spectrosc Radiat Transfer 2011:112:310-9.

[77] Giacomelli M, Chalut K, Ostrander J, Wax A. T-matrix based inverse light scattering analysis using angle resolved low coherence interferometry. Proc SPIE 2009;7187:71870L.

[78] Giacomelli M, Zhu Y, Lee J, Wax A. Size and shape determination of spheroidal scatterers using two-dimensional angle resolved scattering. Opt Express 2010;18:14616-26.

[79] Giacomelli MG, Chalut KJ, Ostrander JH, Wax A. Review of the application of $T$-Matrix calculations for determining the structure of cell nuclei with angle-resolved light scattering measurements. IEEE J Selected Topics Quantum Electron 2010;16:900-8.

[80] Giangrande SE, Luke EP, Kollias P. Automated retrievals of precipitation parameters using non-Rayleigh scattering at $95 \mathrm{GHz}$. J Atmos Oceanic Technol 2010;27:1490-503.

[81] Gogoi A, Rajkhowa P, Choudhury A, Ahmed GA. Development of TUSCAT: a software for light scattering studies on spherical, spheroidal and cylindrical particles. J Quant Spectrosc Radiat Transfer 2011;112:2713-21.

[82] Gong C, Wei H, Li X, et al. The influence of the aspect ratio to the light scattering properties of cylinder ice particles. Acta Opt Sinica 2009;29:1155-9.

[83] Gopinath A, Boriskina SV, Feng N-N, et al. Photonic-plasmonic scattering resonances in deterministic aperiodic structures. Nano Lett 2008;8:2423-31.

[84] Gosset M, Zahiri E-P, Moumouni S. Rain drop size distribution variability and impact on X-band polarimetric radar retrieval: results from the AMMA campaign in Benin. Quart J Roy Meteorol Soc 2010;136:243-56.

[85] Gouesbet G. T-matrix formulation and generalized Lorenz-Mie theories in spherical coordinates. Opt Commun 2010;283:517-21.

[86] Guasoni M, Conforti M. Complex dispersion relation of a double chain of lossy metal nanoparticles. J Opt Soc Am B 2011;28:1019-25.

[87] Guerrero-Martínez A, Alonso-Gómez JL, Auguié B, et al. From individual to collective chirality in metal nanoparticles. Nano Today 2011;6:381-400.

[88] Hajihashemi MR, Jiang H. T-matrix-based inverse algorithm for morphologic characterization of nonspherical particles using multispectral diffuse optical tomography. Appl Opt 2011;50:3896-906.

[89] Hansell RA, Tsay SC, Ji Q et al. An assessment of the surface longwave direct radiative effect of airborne Saharan dust during the NAMMA field campaing. J Atmos Sci 2010;67:1048-65.

[90] Hansell RA, Reid JS, Tsay SC, et al. A sensitivity study on the effects of particle chemistry, asphericity and size on the mass extinction efficiency of mineral dust in the earth's atmosphere: from the near to thermal IR. Atmos Chem Phys 2011;11:1527-47. 
[91] Hayman M, Thayer JP. Lidar polarization measurements of PMCs. J Atmos Sol Terr Phys 2011;73:2110-7.

[92] Hellmers J, Schmidt V, Wriedt T. Improving the numerical stability of $T$-matrix light scattering calculations for extreme particle shapes using the nullfield method with discrete sources. J Quant Spectrosc Radiat Transfer 2011;112:1679-86.

[93] Hervig ME, Gordley LL. Temperature, shape, and phase of mesospheric ice from Solar Occultation for Ice Experiment observations. J Geophys Res 2010;115:D15208.

[94] Hesse E, Macke A, Havemann S, et al. Modelling diffraction by facetted particles. J Quant Spectrosc Radiat Transfer 2012;113:342-7.

[95] Il'in VB, Farafonov VG. Rayleigh approximation for axisymmetric scatterers. Opt Lett 2011;36:4080-2.

[96] Johnson BT, Osborne SR. Physical and optical properties of mineral dust aerosol measured by aircraft during the GERBILS campaign. Quart J Roy Meteorol Soc 2011;137:1117-30.

[97] Kahnert M. Modelling the optical and radiative properties of freshly emitted light absorbing carbon within an atmospheric chemical transport model. Atmos Chem Phys 2010;10:1403-16.

[98] Kahnert M. On the discrepancy between modeled and measured mass absorption cross sections of light absorbing carbon aerosols. Aerosol Sci Technol 2010;44:453-60.

[99] Kahnert M. Numerically exact computation of the optical properties of light absorbing carbon aggregates for wavelength of 200-12.2 $\mu \mathrm{m}$. Atmos Chem Phys 2010;10:8319-29.

[100] Kahnert M, Devasthale A. Black carbon fractal morphology and short-wave radiative impact: a modelling study. Atmos Chem Phys 2011:11:11745-59.

[101] Kahnert M, Rother T. Modeling optical properties of particles with small-scale surface roughness: combination of group theory with a perturbation approach. Opt Express 2011;19:11138-51.

[102] Kahnert M, Nousiainen T, Mauno P. On the impact of nonsphericity and small-scale surface roughness on the optical properties of hematite aerosols. J Quant Spectrosc Radiat Transfer 2011:112:1815-24.

[103] Kardas AE, Markowicz KM, Stelmaszczyk K, et al. Saharan aerosol sensed over Warsaw by backscatter depolarization lidar. Opt Appl 2010;15:219-37.

[104] Kendrick MJ, McIntyre DH, Ostroverkhova O. Wavelenght dependence of optical tweezer trapping forces on dye-doped polystyrene microspheres. J Opt Soc Am B 2009;26:2189-98.

[105] Kennedy PC, Rutledge SA. S-band dual-polarization radar observations of winter storms. J Appl Meteorol Climatol 2011;50:844-58.

[106] Khajeahsani MS, Mohajeri F, Abiri H. Rotational vector addition theorem and its effect on T-matrix. IEEE Trans Antennas Propag 2011;59:3819-25.

[107] Khaled EEM, Aly MEM. Scattering of a focused Gaussian beam by an axisymmetric particle with a nonconcentric spherical core. Phys Scr 2011;83:025101.

[108] Khlebtsov NG. Anisotropic properties of plasmonic nanoparticles: depolarized light scattering, dichroism, and birefringence. J Nanophotonics 2010;4:041587.

[109] Khlebtsov B, Khanadeev V, Pylaev T, Khlebtsov N. A new T-matrix solvable model for nanorods: TEM-based ensemble simulations supported by experiments. J Phys Chem C 2011;115:6317-23.

[110] Kleiber PD, Grassian VH, Young MA, Hudson PK. T-matrix studies of aerosol particle shape effects on IR resonance spectral line profiles and comparison with an experiment. J Geophys Res 2009;114:D21209.

[111] Kobayashi M, Ishibashi D. Absolute rate of turbulent coagulation from turbidity measurement. Colloid Polymer Sci 2011;289:831-6.

[112] Kobayashi E, Uchiyama A, Yamazaki A, Kudo R. Retrieval of aerosol optical properties based on the spheroid model. J Meteorol Soc Japan 2010;88:847-56.

[113] Kobayashi H, Toratani M, Matsumura S, et al. Optical properties of inorganic suspended solids and their influence on ocean colour remote sensing in highly turbid coastal waters. Int J Remote Sens 2011;32:8393-420.

[114] Köhler M, Guillet V, Jones A. Aggregate dust connections and emissivity enhancements. Astron Astrophys 2011;528:A96.

[115] Kolokolova L, Kimura H. Comet dust as a mixture of aggregates and solid particles: model consistent with ground-based and space-mission results. Earth Planets Space 2010;62:17-21.

[116] Kolokolova L, Kimura H. Effects of electromagnetic interaction in the polarization of light scattered by cometary and other types of cosmic dust. Astron Astrophys 2010;513:A40.

[117] Kolokolova L, Liu L, Buratti B, Mishchenko MI. Modeling variations in near-infrared spectra caused by the coherent backscattering effect. J Quant Spectrosc Radiat Transfer 2011;112:2175-81.
[118] Kolokolova L, Sparks W, Mackowski D. Astrobiological remote sensing with circular polarization. In: Mishchenko MI, Yatskiv YS, Rosenbush VK, Videen G, editors. Polarimetric Detection, Characterization, and Remote Sensing. Dordrecht, The Netherlands: Springer; 2011. p. 277-94.

[119] Kolokolova L, Petrova E, Kimura H. Effects of interaction of electromagnetic waves in complex particles. In: Zhurbenko V, editor. Electromagnetic Waves. Rijeka, Croatia: InTech; 2011. p. 173-202.

[120] Krieger UK, Meier P. Observations and calculations of two-dimensional angular optical scattering (TAOS) patterns of a single levitated cluster of two and four microspheres. J Quant Spectrosc Radiat Transfer 2011;112:1761-5.

[121] Kumjian MR, Ryzhkov AV. The impact of evaporation on polarimetric characteristics of rain: theoretical model and practical implications. J Appl Meteorol Climatol 2010;49:1247-67.

[122] Lagarrigue M, Jacquier S, Debayle J, et al. Approximation for the light scattering cross-section of optically hard aggregates. J Quant Spectrosc Radiat Transfer 2012;113:704-14.

[123] Lakhtakia A. Addition theorems for handed spherical vector wavefunctions. Optik 1991;88:187-8.

[124] Lambert A, Santee ML, Wu DL, Chae JH. A-train CALIOP and MLS observations of early winter Antarctic polar stratospheric clouds and nitric acid in 2008. Atmos Chem Phys 2012;12:2899-931.

[125] Lee KH, Kim YJ. Satellite remote sensing of Asian aerosols: a case study of clean, polluted, and Asian dust storm days. Atmos Meas Tech 2010;3:1771-84.

[126] Lee SY, Amsden JJ, Boriskina SV, et al. Spatial and spectral detection of protein monolayers with deterministic aperiodic arrays of metal nanoparticles. Proc Natl Acad Sci USA 2010;107:12086-90.

[127] Leijnse H, Uijlenhoet R. The effect of reported high-velocity small raindrops on inferred drop size distributions and derived power laws. Atmos Chem Phys 2010;10:6807-18.

[128] Leijnse H, Uijlenhoet R. Errors and uncertainties in microwave link rainfall estimation explored using drop size measurements and high-resolution radar data. J Hydrometeorol 2010;11:1330-44.

[129] Leijnse H, Uijlenhoet R, van de Beek CZ, et al. Precipitation measurement at CESAR, the Netherlands. J Hydrometeorol 2010; $11: 1322-9$.

[130] Leinonen J, Moisseev D, Chandrasekar V, Koskinen J. Mapping radar reflectivity values of snowfall between frequency bands. IEEE Trans Geosci Remote Sens 2011;49:3047-58.

[131] Leinonen J, Moisseev D, Leskinen M, Petersen WA. A climatology of disdrometer measurements of rainfall in Finland over five years with implications for global radar observations. J Appl Meteorol Climatol 2012;51:392-404.

[132] Li H, Liu C, Bi L, et al. Numerical accuracy of "equivalent" spherical approximations for computing ensemble-averaged scattering properties of fractal soot aggregates. J Quant Spectrosc Radiat Transfer 2010;111:2127-32.

[133] Li H-Y, Wu Z-S, Bai L. Scattering for charged multisphere structure located in plane wave/Gaussian beam. J Electromagn Waves Appl 2010;24:2037-47.

[134] Li Z-J, Wu Z-S, Li H-Y. Analysis of electromagnetic scattering by uniaxial anisotropic bispheres. J Opt Soc Am A 2011;28:118-25.

[135] Li Z, Zhang Y, Zhang G, Brewster KA. A microphysics-based simulator for advanced airborne weather radar development. IEEE Trans Geosci Remote Sens 2011;49:1356-73.

[136] Li Z-J, Wu Z-S, Shi Y, et al. Multiple scattering of electromagnetic waves by an aggregate of uniaxial anisotropic spheres. J Opt Soc Am A 2012;29:22-31.

[137] Liu C, Li BQ. Computational multiscattering of spherical multilayered gold nanoshells. J Phys Chem C 2011;115:5323-33.

[138] Liu F, Smallwood GJ. Radiative properties of numerically generated fractal soot aggregates: the importance of configuration averaging. J Heat Transfer 2010;132:023308.

[139] Liu F, Smallwood GJ. Effect of aggregation on the absorption crosssection of fractal soot aggregates and its impact on LII modelling. J Quant Spectrosc Radiat Transfer 2010;111:302-8.

[140] Liu F, Smallwood GJ. The effect of particle aggregation on the absorption and emission properties of mono- and polydisperse soot aggregates. Appl Phys B 2011;104:343-55.

[141] Liu L, Wang B, Cao X, et al. Investigation of resonant properties of metal core-shell nanoparticles using $T$-matrix calculations. J Quant Spectrosc Radiat Transfer 2011;112:2733-40

[142] Liu C, Panetta RL, Yang P. The influence of water coating on the optical scattering properties of fractal soot aggregates. Aerosol Sci Technol 2012:46:31-43.

[143] Loke VLY, Asavei T, Nieminen TA, et al. Optimization of opticallydriven micromachines. Proc SPIE 2009;7400:74001Z. 
[144] Loke VLY, Asavei T, Parkin S, et al. Driving optical micromachines with orbital angular momentum. In: Torres JP, Torner L, editors. Twisted Photons. Weinheim, Germany: Wiley-VCH; 2011. p. 93-115.

[145] Loke VLY, Mengüç MP, Nieminen TA. Discrete-dipole approximation with surface interaction: computational toolbox for MATLAB. J Quant Spectrosc Radiat Transfer 2011;112:1711-25.

[146] Lotsberg JK, Stamnes JJ. Impact of particulate oceanic composition on the radiance and polarization of underwater and backscattered light. Opt Express 2010;18:10432-45.

[147] Lumme K, Penttilä A. Model of light scattering by dust particles in the solar system: applications to cometary comae and planetary regoliths. J Quant Spectrosc Radiat Transfer 2011;112:1658-70.

[148] Ma L. Analysis of error in soot characterization using scatteringbased techniques. Particuology 2011;9:210-4.

[149] Mackowski DW. A generalization of image theory to predict the interaction of multipole fields with plane surfaces. J Quant Spectrosc Radiat Transfer 2010;111:802-9.

[150] Mackowski DW, Mishchenko MI. Direct simulation of multiple scattering by discrete random media illuminated by Gaussian beams. Phys Rev A 2011;83:013804.

[151] Mackowski DW, Mishchenko MI. A multiple sphere T-matrix Fortran code for use on parallel computer clusters. J Quant Spectrosc Radiat Transfer 2011;112:2182-92.

[152] Mackowski D, Kolokolova L, Sparks W. T-matrix approach to calculating circular polarization of aggregates made of optically active materials. J Quant Spectrosc Radiat Transfer 2011;112: 1726-32.

[153] Madeleine J-B, Forget F, Millour E, et al. Revisiting the radiative impact of dust on Mars using the LMD global climate model. J Geophys Res 2011;116:E11010.

[154] Makaryan T, Madoyan K, Melikyan A, Minassian H. Theoretica study of surface plasmon frequencies in a system of two coupled spheres and comparison with experimental data. Proc SPIE 2010; 7712: 77121I.

[155] Manago N, Kuze H. Determination of tropospheric aerosol characteristics by spectral measurements of solar radiation using a compact, stand-alone spectroradiometer. Appl Opt 2010;49:1446-58.

[156] Maragò OM, Saija R, Borghese F, et al. Plasmon-enhanced optica trapping of metal nanoparticles: force calculations and lightdriven rotations of nanoaggregates. Proc SPIE 2010;7762:77622Z.

[157] Marcos Seymour JR, Luhar M, et al. Microbial alignment in flow changes ocean light climate. Proc Natl Acad Sci USA 2011;108 3860-4.

[158] Markowicz KM, Witek ML. Simulations of contrail optical properties and radiative forcing for various crystal shapes. J App Meteorol Climatol 2011;50:1740-55.

[159] Maya F, Muhl S, Peña O, Miki-Yoshida M. Synthesis and characterization of silver-carbon nanoparticles produced by highcurrent pulsed arc. Thin Solid Films 2009;518:1484-8.

[160] Megner L, Khaplanov M, Baumgarten G, et al. Large mesospheric ice particles at exceptionally high altitudes. Ann Geophys 2009:27:943-51.

[161] Meland B, Kleiber PD, Grassian VH, Young MA. Correlated IR spectroscopy and visible light scattering measurements of mineral dust aerosol. J Geophys Res 2010;115:D20208.

[162] Meland B, Kleiber PD, Grassian VH, Young MA. Visible light scattering study at 470,550 , and $660 \mathrm{~nm}$ of components of mineral dust aerosol: hematite and goethite. J Quant Spectrosc Radiat Transfer 2011;112:1108-18.

[163] Meland B, Alexander JM, Wong C-S, et al. Evidence for particle size-shape correlations in the optical properties of silicate clay aerosol. J Quant Spectrosc Radiat Transfer 2012;113:549-58.

[164] Melnikov VM, Lee RR, Langlieb NJ. Resonance effects within Sband in echoes from birds. IEEE Geosci Remote Sens Lett 2012;9: 413-6.

[165] Meng Z, Yang P, Kattawar GW, et al. Single-scattering properties of tri-axial ellipsoidal mineral dust aerosols: a database for application to radiative transfer calculations. J Aerosol Sci 2010;41:501-12.

[166] Merchiers O, Eyraud C, Geffrin J-M, et al. Microwave measurements of the full amplitude scattering matrix of a complex aggregate: a database for the assessment of light scattering codes. Opt Express 2010;18:2056-75.

[167] Mierczyk Z, Kopczyński K, Zygmunt M, et al. Fluorescence/ depolarization lidar for mid-range stand-off detection of biological agents. Proc SPIE 2011;8037:80371J.

[168] Mishchenko MI, Dlugach JM. Adhesion of mineral and soot aerosols can strongly affect their scattering and absorption properties. Opt Lett 2012;37:704-6.
[169] Mishchenko MI, Mackowski DW. Coherent backscattering in the cross-polarized channel. Phys Rev A 2011;83:013829.

[170] Mishchenko MI, Dlugach JM, Liu L. Azimuthal asymmetry of the coherent backscattering cone: theoretical results. Phys Rev A 2009;80:053824.

[171] Mishchenko MI, Rosenbush VK, Kiselev NN, et al. Polarimetric remote sensing of solar system objects. Kyiv: Akademperiodyka; 2010. 〈http://arxiv.org/abs/1010.1171〉.

[172] Mishchenko MI, Travis LD, Mackowski DW. T-matrix method and its applications to electromagnetic scattering by particles: a current perspective. J Quant Spectrosc Radiat Transfer 2010;111: 1700-3.

[173] Mishchenko MI, Tishkovets VP, Travis LD, et al. Electromagnetic scattering by a morphologically complex object: fundamental concepts and common misconceptions. J Quant Spectrosc Radiat Transfer 2011;112:671-92.

[174] Mishchenko MI, Dlugach JM, Mackowski DW. Light scattering by wavelength-sized particles "dusted" with subwavelength-sized grains. Opt Lett 2011;36:337-9.

[175] Muinonen K, Tyynelä J, Zubko E, et al. Polarization of light backscattered by small particles. J Quant Spectrosc Radiat Transfer 2011;112:2193-212.

[176] Muller J, Parent G, Jeandel G, Lacroix D. Finite-difference timedomain and near-field-to-far-field transformation in the spectral domain: application to scattering objects with complex shapes in the vicinity of a semi-infinite dielectric medium. J Opt Soc Am A 2011;28:868-78.

[177] Narayanaswamy A, Chen G. Thermal near-field radiative transfer between two spheres. Phys Rev B 2008;77:075125.

[178] Neves AAR, Camposeo A, Pagliara S, et al. Rotational dynamics of optically trapped nanofibers. Opt Express 2010;18:822-30.

[179] Nieminen TA, Loke VLY, Stilgoe AB, et al. T-matrix method for modelling optical tweezers. J Mod Opt 2011;58:528-44.

[180] Niez JJ. Electromagnetic mixing laws: a supersymmetric approach. Ann Phys 2010;325:392-425.

[181] Nishizawa T, Sugimoto N, Matsui I, et al. Algorithms to retrieve optical properties of three component aerosols from two-wavelength backscatter and one-wavelength polarization lidar measurements considering nonsphericity of dust. J Quant Spectrosc Radiat Transfer 2011;112:254-67.

[182] Nousiainen T, Muñoz $\mathrm{O}$, Lindqvist $\mathrm{H}$, et al. Light scattering by large Saharan dust particles: comparison of modeling and experimental data for two samples. J Quant Spectrosc Radiat Transfer 2011;112:420-33.

[183] Nousiainen T, Kahnert M, Lindqvist H. Can particle shape information be retrieved from light-scattering observations using spheroidal model particles? J Quant Spectrosc Radiat Transfer 2011;112:2213-25.

[184] Omar A, Liu Z, Vaughan M, et al. Extinction-to-backscatter ratios of Saharan dust layers derived from in situ measurements and CALIPSO overflights during NAMMA. J Geophys Res 2010;115:D24217.

[185] Onofri FRA, Wozniak M, Barbosa S. On the optical characterisation of nanoparticle and their aggregates in plasma systems. Contr Plasma Phys 2011;51:228-36.

[186] Osborne SR, Baran AJ, Johnson BT, et al. Short-wave and longwave radiative properties of Saharan dust aerosol. Quart J Roy Meteorol Soc 2011;137:1149-67.

[187] Pan Y-L, Berg MJ, Zhang SS-M, et al. Measurement and autocorrelation analysis of two-dimensional light-scattering patterns from living cells for label-free classification. Cytometry A 2011;79:284-92.

[188] Parkin SJ, Vogel R, Persson M, et al. Highly birefringent vaterite microspheres: production, characterization and applications for optical micromanipulation. Opt Express 2009;17:21944-55.

[189] Parsons J, Burrows CP, Sambles JR, Barnes WL. A comparison of techniques used to simulate the scattering of electromagnetic radiation by metallic nanostructures. J Mod Opt 2010;57:356-65.

[190] Paul BB, Yunlong S, Arthur EC. Theoretical prediction for cell deformation in the optical traps. Proc SPIE 2009;7400:74000D.

[191] Paul D, Das SR, Das HS, Sen AK. Polarisation properties of comet NEAT C/2001 Q4. Indian J Phys 2010;84:623-7.

[192] Pawliuk P, Yedlin M. Scattering from cylinders using the two-dimensional vector plane wave spectrum. J Opt Soc Am A 2011;28:1177-84.

[193] Pellegrini YP, Stout DB, Thibaudeau P. Off-shell mean-field electromagnetic $T$-matrix of finite-size spheres and fuzzy scatterers. J Phys Condens Matter 1997;9:177-91.

[194] Pellegrini Y-P, Thibaudeau P, Stout B. The off-shell electromagnetic $T$-matrix: momentum-dependent scattering from spherical 
inclusions with both dielectric and magnetic contacts. Waves Random Complex Media 2011;21:313-35.

[195] Peña-Rodríguez O, Pal U, Campoy-Quiles M, et al. Enhanced Fano resonance in asymmetrical $\mathrm{Au}: \mathrm{Ag}$ heterodimers. J Phys Chem $\mathrm{C}$ 2011;115:6410-4.

[196] Peña-Rodríguez O, Pal U. Enhanced plasmonic behavior of incomplete nanoshells: effect of local field irregularities on the far-field optical response. J Phys Chem C 2011;115:22271-5.

[197] Peña-Rodríguez O, Pal U, Rodríguez-Iglesias V, et al. Configuring $\mathrm{Au}$ and $\mathrm{Ag}$ nanorods for sensing applications. J Opt Soc Am B 2011;28:714-20.

[198] Peng F, Yao B, Yan S, et al. Trapping of low-refractive-index particles with azimuthally polarized beam. J Opt Soc Am B 2009;26:2242-7.

[199] Penttilä A, Lumme K. Optimal cubature on the sphere and other orientation averaging schemes. J Quant Spectrosc Radiat Transfer 2011;112:1741-6.

[200] Pepler AS, May PT, Thurai M. A robust error-based rain estimation method for polarimetric radar. Part I: development of a method. J Appl Meteorol Climatol 2011;50:2092-103.

[201] Petelina SV, Zasetsky AY. Temperature of mesospheric ice particles simultaneously retrieved from $850 \mathrm{~cm}^{-1}$ libration and $3200 \mathrm{~cm}^{-1}$ vibration band spectra measured by ACE-FTS. J Geophys Res 2011;116:D03304.

[202] Petrov D, Shkuratov Y, Videen G. An analytical solution to the light scattering from cube-like particles using Sh-matrices. J Quant Spectrosc Radiat Transfer 2010;111:474-82.

[203] Petrov D, Shkuratov Y, Videen G. The Sh-matrix method applied to light scattering by two merging spheroids. J Quant Spectrosc Radiat Transfer 2010;111:1990-9.

[204] Petrov D, Shkuratov Y, Videen G. Application of the Sh-matrices method to light scattering by spheroids. J Opt 2010;12:095701.

[205] Petrov D, Shkuratov Y, Videen G. Electromagnetic wave scattering from cuboid-like particles using Sh-matrices. J Quant Spectrosc Radiat Transfer 2011;112:155-62.

[206] Petrov D, Shkuratov Y, Videen G. Electromagnetic wave scattering from particles of arbitrary shapes. J Quant Spectrosc Radiat Transfer 2011;112:1636-45.

[207] Petrova EV, Tishkovets VP. Light scattering by aggregates of varying porosity and the opposition phenomena observed in the low-albedo particulate media. J Quant Spectrosc Radiat Transfer 2011;112:2226-33.

[208] Poole LR, Pitts MC, Thomason LW. Comment on "A tropical 'NAT-like' belt observed from space". Geophys Res Lett 2009;36:L20803.

[209] Pruvost J, Van Vooren G, Le Gouic B, et al. Systematic investigation of biomass and lipid productivity by microalgae in photobioreactors for biodiesel application. Bioresource Technol 2011;102:150-8.

[210] Qi H, Wang X-Y, Liu B, Ruan L-M. Determination of the optical constants of non-spherical particles. J Eng Thermophys 2009;30: 837-40.

[211] Quinten M. Optical Properties of Nanoparticle Systems: Mie and Beyond. Weinheim, Germany: Wiley-VCH; 2011.

[212] Quirantes A, Olmo FJ, Valenzuela A, et al. ALFA: a data base for light scattering simulations with atmospheric aerosol applications. Ópt Pura Aplicada 2011;44:641-5.

[213] Rancourt-Grenier S, Wei S, Bai J-J, et al. Dynamic deformation of a soft particle in dual-trap optical tweezers. Proc SPIE 2010; 7762:77621H.

[214] Raut JC, Chazette P. Assessment of vertically-resolved $\mathrm{PM}_{10}$ from mobile lidar observations. Atmos Chem Phys 2009;9:8617-38.

[215] Ridolfo A, Saija R, Savasta S, et al. Fano-Doppler laser cooling of hybrid nanostructures. ACS Nano 2011;5:7354-61.

[216] Rodrígues-Iglesias V, Peña-Rodríguez O, Silva-Pereyra HG, et al. Elongated gold nanoparticles obtained by ion implantation in silica: characterization and $T$-matrix simulations. J Phys Chem C 2010;114:746-51.

[217] Rodríguez-Iglesias V, Peňa-Rodríguez O, Silva-Pereyra HG, et al. Tuning the aspect ratio of silver nanospheroids embedded in silica. Opt Lett 2010;35:703-5.

[218] Rother T. Electromagnetic wave scattering on nonspherical particles. Basic Methodology and Simulations. Berlin: Springer; 2009.

[219] Rother T, Wauer J. Case study about the accuracy behavior of three different T-matrix methods. Appl Opt 2010;49:5746-56.

[220] Roy S, Boro M, Mohanta D, et al. Size quantification of sub-micron ZnSe semiconductor particles by laboratory scattering mrthods. Indian J Phys 2010;84:705-9.

[221] Ruan FX, Zhang SP, Li ZP, et al. Near-field coupling and SERS effects of palladium nanoparticle dimers. Chinese Sci Bull 2010;55:2930-6.
[222] Rubin JT, Deych L. Ab initio theory of defect scattering in spherical whispering-gallery-mode resonators. Phys Rev A 2010;81: 053827.

[223] Rubin JT, Deych L. Effects of spatial confinement of electromagnetic field on optical forces due to whispering-gallery-modes. Proc SPIE 2012;8236:823610.

[224] Ryzhkov A, Pinsky M, Pokrovsky A, Khain A. Polarimetric radar observation operator for a cloud model with spectral microphysics. J Appl Meteorol Climatol 2011;50:873-94.

[225] Sashihithlu K, Narayanaswamy A. Convergence of vector spherical wave expansion method applied to near-field radiative transfer. Opt Express 2011;19:A772-85.

[226] Savasta S, Saija R, Ridolfo A, et al. Nanopolaritons: vacuum Rabi splitting with a single quantum dot in the center of a dimer nanoantenna. ACS Nano 2010;4:6369-76.

[227] Sayer AM, Thomas GE, Grainger RG, et al. Use of MODIS-derived surface reflectance data in the ORAC-AATSR aerosol retrieval algorithm: impact of differences between sensor spectral response functions. Remote Sens Environ 2012;116:177-88.

[228] Schumann U, Weinzierl B, Reitebuch O, et al. Airborne observations of the Eyjafjalla volcano ash cloud over Europe during air space closure in April and May 2011. Atmos Chem Phys 2011;11 2245-79.

[229] Schumann U, Mayer B, Gierens K, et al. Effective radius of ice particles in cirrus and contrails. J Atmos Sci 2011;68:300-21.

[230] Segal-Rosenheimer M, Dubowski Y, Linker R. Extraction of optical constants from mid-IR spectra of small aerosol particles. J Quant Spectrosc Radiat Transfer 2009;110:415-26.

[231] Setién B, Albella P, Saiz JM, et al. Spectral behavior of the linear polarization degree at right-angle scattering configuration for nanoparticle systems. New J Phys 2010;12:103031.

[232] Simpson SH, Hanna S. Orbital motion of optically trapped particles in Laguerre-Gaussian beams. J Opt Soc Am A 2010;27:2061-71.

[233] Simpson SH, Hanna S. Application of the discrete dipole approximation to optical trapping calculations of inhomogeneous and anisotropic particles. Opt Express 2011;19:16526-41.

[234] Skorov YV, Keller HU, Rodin AV. Optical properties of aerosols in Titan's atmosphere: large fluffy aggregates. Planet Space Sci 2010;58:1802-10.

[235] Soderblom LA, Brown RH, Soderblom JM, et al. The geology of Hotei Regio, Titan: Correlation of Cassini VIMS and RADAR. Icarus 2009;204:610-8.

[236] Somerville WRC, Auguié B, Le Ru EC. Simplified expressions of the $T$-matrix integrals for electromagnetic scattering. Opt Lett 2011;36:3482-4.

[237] Somerville WRC, Auguié B, Le Ru EC. Severe loss of precision in calculations of T-matrix integrals. J Quant Spectrosc Radiat Transfer 2012;113:524-35.

[238] Soni J, Purwar H, Ghosh N. Enhanced polarization anisotropy of metal nanoparticles and their spectral characteristics in the surface plasmon resonance band. Proc SPIE 2011;8096:809624.

[239] Soni J, Purwar H, Ghosh N. Quantitative polarimetry of plasmon resonant spheroidal metal nanoparticles: a Mueller matrix decomposition study. Opt Commun 2012;285:1599-607.

[240] Soos M, Lattuada M, Sefcik J. Interpretation of light scattering and turbidity measurements in aggregated systems: effect of intra-cluster multiple-light scattering. J Phys Chem B 2009;113: 14962-70.

[241] Spurr R, Wang J, Zeng J, Mishchenko MI. Linearized T-matrix and Mie scattering computations. J Quant Spectrosc Radiat Transfer 2012;113:425-39.

[242] Stefanou N, Papanikolaou N, Tserkezis C. Plasmonic nanostructures and optical metamaterials: studies by the layer-multiplescattering method. Physica B 2010;405:2967-71.

[243] Stout B, Devilez A, Rolly B, Bonod N. Multipole methods for nanoantennas design: applications to Yagi-Uda configurations. J Opt Soc Am B 2011;28:1213-23.

[244] Strokotov DI, Moskalensky AE, Nekrasov VM, Maltsev VP. Polarized light-scattering profile-advanced characterization of nonspherical particles with scanning flow cytometry. Cytometry A 2011;79:570-9.

[245] Sukhov S, Dogariu A. Negative nonconservative forces: optical "tractor beams" for arbitrary objects. Phys Rev Lett 2011;107:203602.

[246] Sun M, Chen N. Non-invasive measurement of blood glucose level by time-resolved transmission spectroscopy: a feasibility study. Opt Commun 2012;285:1608-12.

[247] Sun X, Wang H, Liu W, Shen J. Nonspherical model for sand dust storm and its application to the research of light multiple scattering. Acta Opt Sinica 2010;30:1506-10. 
[248] Sun XM, Wang HH, Shen J, Liu W. Depolarization and polarization of light scattering by dustlike tropospheric aerosols. J Electromagn Waves Appl 2010;24:1353-64.

[249] Sun X, Wang H, Shen J, Liu W. Depolarization of light backscattering by randomly oriented spheroids with inclusions. J Electromagn Waves Appl 2011;25:1448-58.

[250] Sun X-M, Wang H-H, Shen J, Wang S-J. Scattering of polarized ligh by randomly oriented coated spheroidal particle. Acta Phys Sinica 2011;60:114216.

[251] Sundström A-M, Nousiainen T, Petäjä T. On the quantitative lowlevel aerosol measurements using ceilometer-type lidar. J Atmos Oceanic Technol 2009;26:2340-52.

[252] Tabary P, Vulpiani G, Gourley JJ, et al. Unusually high differential attenuation at $C$ band: results from a two-year analysis of the French Trappes polarimetric radar data. J Appl Meteorol Climatol 2009;48:2037-53.

[253] Tishkovets VP, Petrova EV, Mishchenko MI. Scattering of electromagnetic waves by ensembles of particles and discrete random media. J Quant Spectrosc Radiat Transfer 2011;112:2095-127.

[254] Toledano C, Wiegner M, Gro $\beta$ S, et al. Optical properties of aerosol mixtures derived from sun-sky radiometry during SAMUM-2. Tellus B 2011;63:635-48.

[255] Trevino J, Cao H, Dal Negro L. Circularly symmetric light scattering from nanoplasmonic spirals. Nano Lett 2011;11:2008-16.

[256] Tse KK, Tsang L, Chan CH, Ding KH. Multiple scattering of waves by random distribution of particles for applications in light scattering by metal nanoparticles. In: Maradudin AA, editor. Light Scattering and Nanoscale Surface Roughness. New York: Springer; 2007. p. 341-70.

[257] Tserkezis C, Stefanou N, Papanikolaou N. Effective optical parameters of thin-film and bulk metamaterials of metallodielectric nanosandwiches. Opt Commun 2010;283:4074-7.

[258] Tserkezis C, Stefanou N, Papanikolaou N. Extraordinary refractive properties of photonic crystals of metallic nanorods. J Opt Soc Am B 2010;27:2620-7.

[259] Tyynelä J, Leinonen J, Moisseev D, Nousiainen T. Radar backscattering from snowflakes: comparison of fractal, aggregate, and soft spheroid models. J Atmos Oceanic Technol 2011;28:1365-72.

[260] Vaillon R, Geffrin J-M, Eyraud C, et al. A new implementation of a microwave analog to light scattering measurement device. Quant Spectrosc Radiat Transfer 2011;112:1753-60.

[261] Valenzuela A, Olmo FJ, Lyamani H, et al. Analysis of the columnar radiative properties retrieved during African desert dust events over Granada (2005-2010) using principal plane sky radiances and spheroids retrieval procedure. Atmos Res 2012;104-105:292-301.

[262] Veselovskii I, Dubovik O, Kolgotin A, et al. Application of randomly oriented spheroids for retrieval of dust particle parameters from multiwavelength lidar measurements. J Geophys Res 2010;115:D21203.

[263] Vincendon M, Pilorget C, Gondet B, et al. New near-IR observations of mesospheric $\mathrm{CO}_{2}$ and $\mathrm{H}_{2} \mathrm{O}$ clouds on Mars. J Geophys Res 2011;116:E00J02.

[264] Vinokurov AA, Il'in VB, Farafonov VG. On optical properties of nonspherical inhomogeneous particles. Opt Spectrosc 2010;109: 444-53.

[265] Vinokurov AA, Il'in VB, Farafonov VG. ScattPy: a new Python package for light scattering computations. J Quant Spectrosc Radiat Transfer 2011;112:1733-40.

[266] Voit F, Schäfer J, Kienle A. Light scattering by multiple spheres: solutions of Maxwell theory compared to radiative transfer theory. Proc SPIE 2009;7371:73711G.

[267] Vulpiani G, Giangrande S, Marzano FS. Rainfall estimation from polarimetric S-band radar measurements: validation of a neural network approach. J Appl Meteorol Climatol 2009;48: 2022-36.

[268] Wagner R, Ajtai T, Kandler K, et al. Complex refractive indices of Saharan dust samples at visible and near UV wavelengths: a laboratory study. Atmos Chem Phys 2012;12:2491-512.

[269] Wang JJ, Gouesbet G, Han YP, Gréhan G. Study of scattering from a sphere with an eccentrically located spherical inclusion by generalized Lorenz-Mie theory: internal and external field distribution. J Opt Soc Am A 2011;28:24-39.

[270] Wang J, Gréhan G, Han Y, et al. Numerical study of global rainbow technique: sensitivity to non-sphericity of droplets. Exp Fluids 2011;51:149-59.
[271] Wang JJ, Gouesbet G, Gréhan G, et al. Morphology-dependent resonances in an eccentrically layered sphere illuminated by a tightly focused off-axis Gaussian beam: parallel and perpendicular beam incidence. J Opt Soc Am A 2011;28:1849-59.

[272] Wax A, Chalut KJ. Nuclear morphology measurements with angleresolved low coherence interferometry for application to cell biology and early cancer detection. Anal Cellular Pathol 2011;34: 207-22.

[273] Wheeler MS, Aitchison JS, Mojahedi M. Coupled magnetic dipole resonances in sub-wavelength dielectric particle clusters. J Opt Soc Am B 2010;27:1083-91.

[274] Wiensz JT, Bourassa AE, Lloyd ND, et al. Photon conservation in scattering by large ice crystals with the SASKTRAN radiative transfer model. J Quant Spectrosc Radiat Transfer 2012;113:582-93.

[275] Willingham B, Link S. Energy transport in metal nanoparticle chains via sub-radiant plasmon modes. Opt Express 2011;19: 6450-61.

[276] Winker DM, Liu Z, Omar A, et al. CALIOP observations of the transport of ash from the Eyjafjallajökull volcano in April 2010. J Geophys Res 2012;117:D00U15.

[277] Wolff MJ, Clancy RT, Goguen JD, et al. Ultraviolet dust aerosol properties as observed by MARCI. Icarus 2010;208: 143-55.

[278] Wu H, Tsoutsoura A, Lattuada M, et al. Effect of temperature on high shear-induced gelation of charge-stabilized colloids without adding electrolytes. Langmuir 2010;26:2761-8.

[279] Xie X, Löhnert U, Kneifel S, Crewell S. Snow particle orientation observed by ground-based microwave radiometry. J Geophys Res 2012;117:D02206.

[280] Xing JA, Sun XG, Yuan GB, et al. Backscattering spectrum analysis of nonspheroid soot particle. Spectrosc Spectral Anal 2010;30: 2239-42.

[281] Xu F, Davis AB. Derivatives of light scattering properties of a nonspherical particle computed with the $T$-matrix method. Opt Lett 2011;36:4464-6.

[282] Xu F, Lock JA. Debye series for light scattering by a coated nonspherical particle. Phys Rev A 2010;81:063812.

[283] Xu S, Sun Z. Evaluation of the uncertainties caused by the forward scattering in turbidity measurement of the coagulation rate. Langmuir 2010;26:6908-18.

[284] Xu F, Lock JA, Gouesbet G. Debye series for light scattering by a nonspherical particle. Phy Rev A 2010;81:043824.

[285] Yang S, Taflove A, Backman V. Experimental confirmation at visible light wavelengths of the backscattering enhancement phenomenon of the photonic nanojet. Opt Express 2011;19: 7084-93.

[286] Yao B-L, Yan S-H, Ye T, Zhao W. Optical trapping of double-ring radially polarized beam with improved axial trapping efficiency. Chinese Phys Lett 2010;27:108701.

[287] Yi B, Hsu CN, Yang P, Tsay S-C. Radiative transfer simulation of dust-like aerosols: uncertainties from particle shape and refractive index. J Aerosol Sci 2011;42:631-44.

[288] Yin JY, Liu LH. Radiative property of multi-particle soot cluster formed by different diameter and component. Am Inst Phys Conf Proc 2010;1207:598-603.

[289] Yin JY, Liu LH. Influence of complex component and particle polydispersity on radiative properties of soot aggregate in atmosphere. J Quant Spectrosc Radiat Transfer 2010;111: 2115-26.

[290] Yurkin MA, de Kanter D, Hoekstra AG. Accuracy of the discrete dipole approximation for simulation of optical properties of gold nanoparticles. J Nanophotonics 2010;4:041585.

[291] Zinevich A, Messer H, Alpert P. Prediction of rainfall intensity measurement errors using commercial microwave communication links. Atmos Meas Tech 2010;3:1385-402.

[292] Khlebtsov BN, Khanadeev VA, Khlebtsov NG. Attenuation, scattering, and depolarization of light by gold nanorods with silver shells. Opt Specterosc 2010;108:59-69.

[293] Khlebtsov B, Khanadeev V, Khlebtsov N. Tunable depolarized light scattering from gold and gold/silver nanorods. Phys Chem Chem Phys 2010;12:3210-8.

[294] Waterman PC. Symmetry, unitarity, and geometry in electromagnetic scattering. Phys Rev D 1971;3:825-39. 